\title{
Inflammation Activates the Interferon Signaling Pathways in Taste Bud Cells
}

\author{
Hong Wang, ${ }^{1}$ Minliang Zhou, ${ }^{1}$ Joseph Brand, ${ }^{1,2}$ and Liquan Huang ${ }^{1}$ \\ ${ }^{1}$ Monell Chemical Senses Center, Philadelphia, Pennsylvania 19104-3308, and ${ }^{2}$ Department of Biochemistry, School of Dental Medicine, University of \\ Pennsylvania, Philadelphia, Pennsylvania 19104
}

\begin{abstract}
Patients with viral and bacterial infections or other inflammatory illnesses often experience taste dysfunctions. The agents responsible for these taste disorders are thought to be related to infection-induced inflammation, but the mechanisms are not known. As a first step in characterizing the possible role of inflammation in taste disorders, we report here evidence for the presence of interferon (IFN)mediated signaling pathways in taste bud cells. IFN receptors, particularly the IFN- $\gamma$ receptor IFNGR1, are coexpressed with the taste cell-type markers neuronal cell adhesion molecule and $\alpha$-gustducin, suggesting that both the taste receptor cells and synapse-forming cells in the taste bud can be stimulated by IFN. Incubation of taste bud-containing lingual epithelia with recombinant IFN- $\alpha$ and IFN- $\gamma$ triggered the IFN-mediated signaling cascades, resulting in the phosphorylation of the downstream STAT1 (signal transducer and activator of transcription protein 1) transcription factor. Intraperitoneal injection of lipopolysaccharide or polyinosinic:polycytidylic acid into mice, mimicking bacterial and viral infections, respectively, altered gene expression patterns in taste bud cells. Furthermore, the systemic administration of either IFN- $\alpha$ or IFN- $\gamma$ significantly increased the number of taste bud cells undergoing programmed cell death. These findings suggest that bacterial and viral infection-induced IFNs can act directly on taste bud cells, affecting their cellular function in taste transduction, and that IFN-induced apoptosis in taste buds may cause abnormal cell turnover and skew the representation of different taste bud cell types, leading to the development of taste disorders. To our knowledge, this is the first study providing direct evidence that inflammation can affect taste buds through cytokine signaling pathways.
\end{abstract}

Key words: inflammation; cytokine; interferon; gene expression; taste bud; taste disorder

\section{Introduction}

Chemosensory disorders (taste and smell) impact negatively on general health and quality of life (Deems et al., 1991; Graham et al., 1995; Schiffman and Graham, 2000). The number of people suffering from these disorders is estimated to be in the millions (Hoffman et al., 1998; Murphy et al., 2002; Brämerson et al., 2004; Landis et al., 2004). Although a number of conditions, such as nutritional compromise, oral appliances, medications, and aging, can contribute to or exacerbate taste deficits, viral and bacterial infections are among the most common causes (Mistretta, 1984; Bartoshuk et al., 1987; Goodspeed et al., 1987; Heald et al., 1998; Cullen and Leopold, 1999; Pribitkin et al., 2003).

The immune response to viral and bacterial infections is mediated by cytokines. Interferons (IFNs) are one of the major groups of cytokines critical in fighting these invaders (Kalvakolanu, 2003; Stetson and Medzhitov, 2006), yet, in excess, IFNs are also potentially toxic, contributing to anorexia, cachexia, and a variety of inflammatory and autoimmune illnesses (Yeh and

\footnotetext{
Received Feb. 7, 2007; revised Aug. 20, 2007; accepted Aug. $20,2007$.

This work was in part supported by National Institutes of Health Grants DC007974 (H.W.) and DC05154 (L.H.) and National Science Foundation Grant DBJ-0216310 (N. Rawson). We thank Dr. Peter Lengyel for valuable discussions and suggestions.

Correspondence should be addressed to Liquan Huang, Monell Chemical Senses Center, 3500 Market Street Philadelphia, PA 19104. E-mail: Ihuang@monell.org.

DOI:10.1523/JNEUROSCI.3102-07.2007

Copyright $\odot 2007$ Society for Neuroscience 0270-6474/07/2710703-11\$15.00/0
}

Schuster, 1999; Crow, 2003; Theofilopoulos et al., 2005; Banchereau and Pascual, 2006). Intriguingly, some patients with chronic inflammatory and autoimmune diseases often complain of taste dysfunctions (Mann, 2002; Bromley and Doty, 2003). Finally, long-term use of IFN- $\alpha$ as medication for cancer or viral infection is associated with taste and smell disorders (Jones and Itri, 1986; Kellokumpu-Lehtinen et al., 1989; Kraus and Vitezic, 2000; Abdollahi and Radfar, 2003).

A common thread running through many of these chemosensory disorders is the likely presence of inflammation. Several investigations have reported that inflammation induced by radiation to the oral cavity often leads to hypogeusia or ageusia (Conger and Wells, 1969; Esses et al., 1988; Nelson, 1998; Yamashita et al., 2006). These studies have shown alterations in taste bud cell structure, extensive loss of taste bud cells, or even entire taste buds. In addition, alterations in taste cell structure have been reported in taste bud biopsies from patients with postinfluenza-like hypogeusia (Henkin et al., 1975).

Until now, the reports of the likely contribution of inflammation to taste disorders have been generally descriptive, with the actual mechanisms being primarily a matter of speculation (Mann, 2002). In the present study, we hypothesize that IFNs produced during infection and chronic inflammation induce taste bud cell apoptosis, triggering the development of taste disorders. To test this hypothesis, we sought to characterize possible IFN signaling pathways in rodent taste epithelium. Here we re- 
port the expression of type I and type II IFN receptors and their downstream signaling components in functionally different subsets of taste bud cells. Inflammation induced by the viral infection-mimicking double-stranded RNA (dsRNA) or the bacterial endotoxin lipopolysaccharide (LPS) activated these pathways, leading to the induction of multiple IFN-inducible genes in taste epithelium. Furthermore, IFN treatment significantly increases apoptotic cell death in taste buds.

Our results suggest that activation of IFN signaling pathways may disrupt the homeostasis of cell turnover in taste buds, interfere with taste signal transduction and transmission, and, as a result, contribute to the development of taste disorders.

\section{Materials and Methods}

Animals. All studies involving animals were performed according to protocols approved by the Monell Chemical Senses Center Institutional Animal Care and Use Committee. C57BL/6 mice and Sprague Dawley rats were housed in a climate-controlled environment at the Animal Care Facility of Monell Chemical Senses Center.

Reagents. Rabbit polyclonal antibodies against signal transducer and activator of transcription protein 1 (STAT1) p84/p91 (sc-346) (Begitt et al., 2000), $\alpha$-gustducin (sc-395) (Pumplin and Getschman, 2000; Finger et al., 2005), and the IFN- $\gamma$ receptor IFNGR1 (sc-700) (Royuela et al., 2000; Federici et al., 2002), and the blocking peptide (sc-700p) to IFNGR1 antibody were purchased from Santa Cruz Biotechnology (Santa Cruz, CA). Mouse monoclonal antibodies against neuronal cell adhesion molecule (NCAM) (C9672) (Yee et al., 2001) and $\beta$-actin (A5441) (Garnier et al., 2003), recombinant mouse IFN- $\alpha$ A, LPS, and polyinosinic:polycytidylic acid [poly(I:C)] were purchased from Sigma (St. Louis, MO). Rabbit polyclonal antibodies against phospho-STAT1 [tyrosine residue 701 (Tyr701); catalog \#9171] (Begitt et al., 2000; Spagnoli et al., 2002), cleaved caspase-3 (catalog \#9661) (Sánchez-Gómez et al., 2003; Saito et al., 2004), and cleaved poly(ADP-ribose) polymerase (PARP) (catalog \#9544) (Garnier et al., 2003) were purchased from Cell Signaling Technology (Danvers, MA). Cyanine 3 (Cy3)-conjugated goat anti-rabbit and FITC-conjugated donkey anti-mouse antibodies were purchased from Jackson ImmunoResearch (West Grove, PA). The Zenon rabbit antibody labeling kit was purchased from Invitrogen (Carlsbad, CA). Recombinant murine IFN- $\gamma$ was from PeproTech (Rocky Hill, $\mathrm{NJ})$. Collagenase A and dispase II were from Roche Applied Science (Indianapolis, IN).

Reverse transcription-PCR analysis. Tongues were immediately excised from killed C57BL/6 mice and placed in the calcium-free Tyrode's buffer (in mm: $140 \mathrm{NaCl}, 5 \mathrm{KCl}, 10$ HEPES, $1 \mathrm{MgCl}_{2}, 10$ glucose, $10 \mathrm{Na}$ pyruvate, and 2 EGTA, pH 7.4). The excised tongue was injected subepithelially with a mixture of dispase II $(2 \mathrm{mg} / \mathrm{ml})$ and collagenase A (1 $\mathrm{mg} / \mathrm{ml}$ ) in $\mathrm{Ca}^{2+}$-free Tyrode's solution and incubated at $37^{\circ} \mathrm{C}$ for 20 $\mathrm{min}$. The epithelium was peeled off and washed three times with calciumcontaining PBS (catalog \#14040-117; Invitrogen). The circumvallate and foliate papillae were excised, and the anterior part of the lingual epithelium with the highest density of fungiform papillae was also collected.

Total RNA was extracted from taste epithelia using Trizol reagent (Invitrogen). cDNA was synthesized from equal amounts of the total RNA from these tissue samples using SuperScript III reverse transcriptase (Invitrogen). PCR analyses were performed with these samples using gene-specific primers that covered the entire open reading frame and often included multiple exons [except for Janus kinase 2 (Jak2) and $\beta$-actin] to monitor possible contamination from genomic DNA. PCR products were cloned into pCR-Blunt II-TOPO vector (Invitrogen) and sequenced to verify their identities. The primers used are listed in Table 1.

Quantitative real-time PCR analysis. Total RNA was extracted using Absolutely RNA Microprep kit (Stratagene, Cedar Creek, TX) from peeled-off epithelial pieces that either lacked taste buds (excised from within the intermolar eminence) or contained foliate or circumvallate taste buds. Approximately equal amounts of total RNA from these tissues were reverse transcribed into cDNA using Superscript III reverse transcriptase (Invitrogen). Power SYBR Green PCR Master Mix (Applied Biosystems, Foster City, CA) was used to set up real-time PCR reactions. The assays were run in an ABI PRISM 7000 Sequence Detection System (Applied Biosystems). The specificity of the PCR reactions was analyzed by dissociation studies using the Applied Biosystems instrument and confirmed by agarose gel electrophoresis. Gene expression levels were quantified using the Applied Biosystems software and exported to Excel (Microsoft, Seattle, WA) for graphic presentation. Relative quantification was determined using the $2^{-\Delta \Delta C t}$ method (Livak and Schmittgen, 2001), which normalizes the expression levels of genes of interest against those of "housekeeping" genes in the same samples and then compares the expression levels among control and treatment samples. Real-time PCR primers (Table 2 ) were designed to have nearly the same annealing temperature.

To determine the effect of systemic administration of LPS and poly(I:C) on the expression of IFN-inducible genes and c-fos in taste tissues, LPS (5 mg/kg in PBS), poly(I:C) (25 mg/kg in PBS), or PBS vehicle was injected intraperitoneally into three groups (nine per group) of adult C57BL/6 mice, respectively. Six hours after injection, mice were killed, and tongue epithelium was prepared as described above. Total RNA was extracted from peeled-off epithelial pieces using Absolutely RNA Microprep kit (Stratagene) and reverse transcribed into first-strand cDNAs, which were used as templates for quantitative real-time PCR with the PCR primers (Table 2) for c-fos and five IFN-inducible genes: 2-5A synthetase, IFN regulatory factor-1 (Irf1), myxovirus resistance protein $1(M x 1)$, dsRNA-dependent protein kinase $(P k r)$, and Stat1.

In situ hybridization. Digoxigenin (DIG)-labeled sense and antisense cRNA probes corresponding to the entire coding region of mouse Ifngr I and Irf1 were synthesized using the DIG RNA labeling kit (Roche Applied Science). The RNA probes were then alkaline hydrolyzed into $\sim 300$-ntlong fragments. Fresh-frozen mouse taste sections (14 $\mu \mathrm{m} /$ section) were attached to clean SuperFrost/Plus slides (Fisher Scientific, Pittsburgh, PA) and processed for in situ hybridization as described previously 
Table 2. Real-time PCR primers

\begin{tabular}{|c|c|c|c|c|}
\hline Gene & GenBank accession number & Orientation & Sequence & Product size (bp) \\
\hline \multirow[t]{2}{*}{ Ifnar1 } & \multirow[t]{2}{*}{ NM_010508 } & Forward & TCCCCGCAGTATTGATGAGT & \multirow[t]{2}{*}{171} \\
\hline & & Reverse & CTGGTCTGTGAGCTGTACTT & \\
\hline \multirow[t]{2}{*}{ Ifnar2 } & \multirow[t]{2}{*}{ NM_010509 } & Forward & CTATCGTAATGCTGAAACGG & \multirow[t]{2}{*}{171} \\
\hline & & Reverse & CGTAATTCCACAGTCTCTTCT & \\
\hline \multirow[t]{2}{*}{ Ifngr1 } & \multirow[t]{2}{*}{ M28233 } & Forward & TGTTACCTAAGTCCTTGCTC & \multirow[t]{2}{*}{181} \\
\hline & & Reverse & TCTTCCTGTTCTGCTGCTTC & \\
\hline \multirow[t]{2}{*}{ Ifngr2 } & \multirow[t]{2}{*}{ NM_008338 } & Forward & GTTCCTCAAATACCAAAGCC & \multirow[t]{2}{*}{162} \\
\hline & & Reverse & ATAATTGACACGGAGTCCCA & \\
\hline \multirow[t]{2}{*}{ 2-5A synthetase } & \multirow[t]{2}{*}{ NM_145211 } & Forward & CTTTGATGTCCTGGGTCATGT & \multirow[t]{2}{*}{122} \\
\hline & & Reverse & GCTCCGTGAAGCAGGTAGAG & \\
\hline \multirow[t]{2}{*}{ Irf-1 } & \multirow[t]{2}{*}{ NM_008390 } & Forward & AGAGGAACCAGAGATTGACAGC & \multirow[t]{2}{*}{177} \\
\hline & & Reverse & GTCAGAGACCCAAACTATGGTGC & \\
\hline \multirow[t]{2}{*}{$M \times 1$} & \multirow[t]{2}{*}{ NM_010846 } & Forward & GAAGGCAAGGTCTTGGATG & \multirow[t]{2}{*}{82} \\
\hline & & Reverse & GCTGACCTCTGCACTTGACT & \\
\hline \multirow[t]{2}{*}{$P k r$} & \multirow[t]{2}{*}{ NM_011163 } & Forward & AACTTCTTCACACGTGCTTC & \multirow[t]{2}{*}{181} \\
\hline & & Reverse & CATTCAGCCAAGGTCTTCAG & \\
\hline \multirow[t]{2}{*}{ Stat1 } & \multirow[t]{2}{*}{ NM_009283 } & Forward & GACCCTAAGCGAACTGGATAC & \multirow[t]{2}{*}{191} \\
\hline & & Reverse & TGTCGCCAGAGAGAAATTCGTGT & \\
\hline \multirow[t]{2}{*}{ c-fos } & \multirow[t]{2}{*}{ NM_010234 } & Forward & GAGCTGACAGATACACTCCAA & \multirow[t]{2}{*}{164} \\
\hline & & Reverse & TCTGGGAAGCCAAGGTCATCG & \\
\hline \multirow[t]{2}{*}{ Gapdh } & \multirow[t]{2}{*}{ NM_001001303 } & Forward & TACAGCAACAGGGTGGTGGA & \multirow[t]{2}{*}{139} \\
\hline & & Reverse & GTGAGGGAGATGCTCAGTGT & \\
\hline
\end{tabular}

(Schaeren-Wiemers and Gerfin-Moser, 1993; Huang et al., 2005). Briefly, hybridizations were performed at $70^{\circ} \mathrm{C}$ overnight with the hydrolyzed digoxigenin-labeled probes in $50 \%$ formamide, $5 \times$ SSC, $5 \times$ Denhardt's solution, $250 \mu \mathrm{g} / \mathrm{ml}$ yeast RNA, and $500 \mu \mathrm{g} / \mathrm{ml}$ sperm DNA. Sections were washed three times at $72^{\circ} \mathrm{C}$ with $0.2 \times$ SSC. Signals were detected using alkaline-phosphatase-conjugated anti-digoxigenin antibodies and standard chromogenic substrates (Roche Applied Science).

Immunohistochemistry. Excised mouse or rat tongue tissues were fixed in freshly prepared $4 \%$ paraformaldehyde/PBS for $1 \mathrm{~h}$ on ice and then cryoprotected in $20 \%$ sucrose/PBS solution at $4^{\circ} \mathrm{C}$ overnight. Tissues were embedded in mounting medium and sliced into 10 - to $12-\mu \mathrm{m}$-thick sections. Sections were blocked in the blocking buffer (3\% BSA, $0.3 \%$ Triton X-100, 2\% goat serum, and $0.1 \%$ sodium azide in PBS) for $1 \mathrm{~h}$ at room temperature and then incubated overnight at $4^{\circ} \mathrm{C}$ with rabbit polyclonal antibodies against IFNGR1 (Santa Cruz Biotechnology) or cleaved caspase-3 (Cell Signaling Technology). The secondary antibody was Cy3conjugated goat anti-rabbit IgG. To test the specificity of the antiIFNGR1 antibody, diluted antibody was first incubated with the antigenic peptide (sc-700p; Santa Cruz Biotechnology) at a concentration of $10 \mu \mathrm{g}$ peptide per $1 \mu \mathrm{g}$ antibody at room temperature for $1.5 \mathrm{~h}$. The blocked antibody was then added to the tissue sections.

To determine the coexpression of IFNGR1 with other known taste signaling proteins and cell-type markers, double immunostaining was performed on rat taste sections because one of the primary antibodies was mouse monoclonal antibody, which often generates high background staining on mouse tissue sections but low background on rat sections. For the colocalization study of IFNGR1 and NCAM, we used rabbit polyclonal antibody against IFNGR1 (Santa Cruz Biotechnology) and mouse monoclonal antibody against NCAM (Sigma). Secondary antibodies were $\mathrm{Cy} 3$ - and FITC-conjugated goat anti-rabbit and donkey anti-mouse antibodies, respectively. For colocalization of IFNGR1 and $\alpha$-gustducin, taste sections were first incubated with anti-IFNGR1 antibody followed by secondary Cy3-conjugated goat anti-rabbit antibody, washed, and then incubated with Alexa488-labeled $\alpha$-gustducin antibody; the primary antibody labeling was performed using the Zenon rabbit IgG labeling kit (Invitrogen). Images were taken using a Leica (Nussloch, Germany) TCS SP2 spectral confocal microscope. Six rat circumvallate sections from two animals were examined to determine the number of immunoreactive taste bud cells.

Western blot analyses. To characterize IFN-induced STAT1 phosphorylation, mouse lingual epithelium was freed from the rest of the tongue as described above. Fungiform, foliate, and circumvallate papillae and a piece of control tissue (lingual epithelium devoid of taste buds) were incubated in OptiMEM medium (Invitrogen) at $37^{\circ} \mathrm{C}$ in a $5 \% \mathrm{CO}_{2}$ incubator for $1 \mathrm{~h}$, followed by treatment with recombinant murine IFN- $\alpha$ A $\left(5 \times 10^{3}\right.$ units/ml $)$, IFN- $\gamma\left(1 \times 10^{4}\right.$ units $/ \mathrm{ml}$ ), or vehicle (buffer only) for an additional $1 \mathrm{~h}$. These tissues were collected, and protein samples were prepared in Laemli's sample buffer (Bio-Rad, Hercules, CA) with $\beta$-mercaptoethanol for SDS-PAGE and then transferred to polyvinylidene difluoride membranes.

To detect and quantify the phosphorylation of STAT1, Western blots were first incubated with phospho-STAT1 (Tyr701)-specific antibody (Cell Signaling Technology) and then stripped and reprobed with anti-STAT1 rabbit polyclonal antibody (Santa Cruz Biotechnology) and anti- $\beta$-actin mouse monoclonal antibody (Sigma). The secondary antibodies were horseradish peroxidase-conjugated anti-rabbit or anti-mouse antibodies, which were detected with an enhanced chemiluminescence detection system (ECL Western Blotting Analysis System; GE Healthcare, Pittsburgh, PA). The chemiluminescently exposed $\mathrm{x}$-ray films were scanned, and the signal intensities were analyzed and quantified using AlphaEaseFC/Alpha Imager 2000 software (Alpha Innotech, San Leandro, CA). The level of STAT1 phosphorylation was normalized against the level of $\beta$-actin in each sample. The level of phospho-STAT1 in the vehicle-treated nontaste lingual epithelium was arbitrarily set to 1 . Five independent experiments were performed to determine SEM.

To examine IFN-induced apoptosis in taste buds, taste and nontaste lingual epithelia were prepared as described above and cultured for $48 \mathrm{~h}$ in the culture medium only (DMEM supplemented with $10 \%$ fetal bovine serum) or culture medium supplemented with the recombinant mouse IFN- $\alpha\left(5 \times 10^{3}\right.$ units $\left./ \mathrm{ml}\right)$ or IFN- $\gamma\left(2 \times 10^{4}\right.$ units $\left./ \mathrm{ml}\right)$. Cell lysates were prepared in Laemli's sample buffer (Bio-Rad) with $\beta$-mercaptoethanol and analyzed with Western blotting and antibodies against cleaved PARP and $\beta$-actin as described above.

Measurement of IFN-induced apoptosis in taste buds. Groups of six C57BL/ 6 mice with body weight of $\sim 25$ g were intraperitoneally injected daily with PBS, IFN- $\alpha\left(5 \times 10^{3}\right.$ units in PBS per animal), or IFN- $\gamma(2 \times$ $10^{4}$ units in PBS per animal) for 2 or $5 \mathrm{~d}$. Three mice from each group were killed on either day 2 or day 5 . Tongues from these mice were fixed and sectioned for immunostaining as described above. Serial $10-\mu \mathrm{m}-$ thick sections of circumvallate papillae were stained with the antibody against cleaved caspase- 3 . To count the number of taste buds that were immunoreactive to the cleaved caspase-3 antibody, 4',6-diamidino-2phenylindole (DAPI)-containing mounting medium was used to visualize the nuclei, which helped determine the outlines of the onion-shaped taste buds. Because the modal diameter of a mouse taste bud is $\sim 35-40$ $\mu \mathrm{m}$ (Zeng and Oakley, 1999), to avoid repetitive counting of the same buds, every fourth section of 10 - $\mu \mathrm{m}$-thick circumvallate slices was included for determining the total number of taste buds on each section and the number of the cleaved caspase-3-positive taste buds. On average, data from six or seven circumvallate sections from each animal were collected, and three animals from each group were used for each time point.

\section{Results}

Taste epithelia express key components of the IFN signaling pathways

In our continuing endeavors to isolate taste bud cell-specific genes, we have frequently encountered the genes that are involved in the IFN signaling pathways (Huang et al., 1999, 2005; 
Perez et al., 2002). IFNs, consisting of type I IFNs (including IFN- $\alpha$, IFN- $\beta$, IFN- $\omega$, IFN $-\tau$, IFN $-\delta$, IFN $-\kappa$, and IFN- $\varepsilon$ ) and type II IFN (IFN- $\gamma)$, can, either alone or in concert with other cytokines, induce apoptosis, inhibit cell proliferation, and adversely affect development and maturation (Gresser, 1990; Kalvakolanu, 2000; Taniguchi and Takaoka, 2001; Chawla-Sarkar et al., 2003; Caraglia et al., 2005). Our isolation of some IFN signaling molecules from taste bud cells and previous reports from other laboratories showing that IFN- $\alpha$, when taken as medication, causes taste disorders (Jones and Itri, 1986; Kellokumpu-Lehtinen et al., 1989; Abdollahi and Radfar, 2003) prompted us to thoroughly investigate the IFN pathways in taste cells.

To evaluate the possibility that IFNs may be active in the etiology of taste disorders, we first needed to determine whether the genes for several key components of IFN signaling pathways are expressed in taste tissues. Previous studies in other tissues identified several major components of the signaling pathways for types I and II IFNs (Darnell, 1997; Pestka, 1997; Taniguchi and Takaoka, 2001; Kalvakolanu, 2003). Type I and type II IFNs initiate two similar but distinct signaling pathways (for details, see Fig. $1 A$ ): type I IFNs (including IFN- $\alpha$ ) bind to their heterodimeric receptor IFN- $\alpha \mathrm{R} 1 / \mathrm{IFN}-\alpha \mathrm{R} 2$ or IFN- $\alpha$ receptor (IFNAR1)/IFNAR2, whereas type II IFNs $(\mathrm{IFN}-\gamma)$ act on the tetrameric receptors consisting of two polypeptides IFN- $\gamma \mathrm{R} 1$, IFN- $\gamma$ R2 or IFNGR1, IFNGR2. Activation of IFN receptors triggers a number of downstream signaling molecules, including the JAK, protein tyrosine kinase 2 (TYK2), and the STAT transcription factors (Taniguchi and Takaoka, 2001; Kalvakolanu, 2003; van Boxel-Dezaire et al., 2006), which eventually leads to upregulation of a large number of IFN-inducible genes. Some of these gene products, such as IRF-1, PKR, and the IFN-inducible protein 202, strongly suppress cell proliferation and cell differentiation and promote apoptosis (Tanaka et al., 1994; Choubey et al., 1996; Lee et al., 1997; Der et al., 1998; Wang et al., 2000, 2002).

A search for the likely expression of many of the signaling molecules outlined in Figure $1 \mathrm{~A}$ demonstrated the presence of message for almost all. Reverse transcription (RT)-PCR analyses with RNA samples prepared from tongue epithelium containing fungiform, foliate, and circumvallate papillae showed that the two IFN- $\alpha$ receptor subunits IFNAR1 and IFNAR2, their downstream JAK kinases JAK1 and TYK2, and the transcription factors STAT1, STAT2, and IRF-9 were all expressed in normal taste epithelial samples (Fig. 1B). Interestingly, we found that two different-sized PCR products were detected for IFNAR2 (Fig.
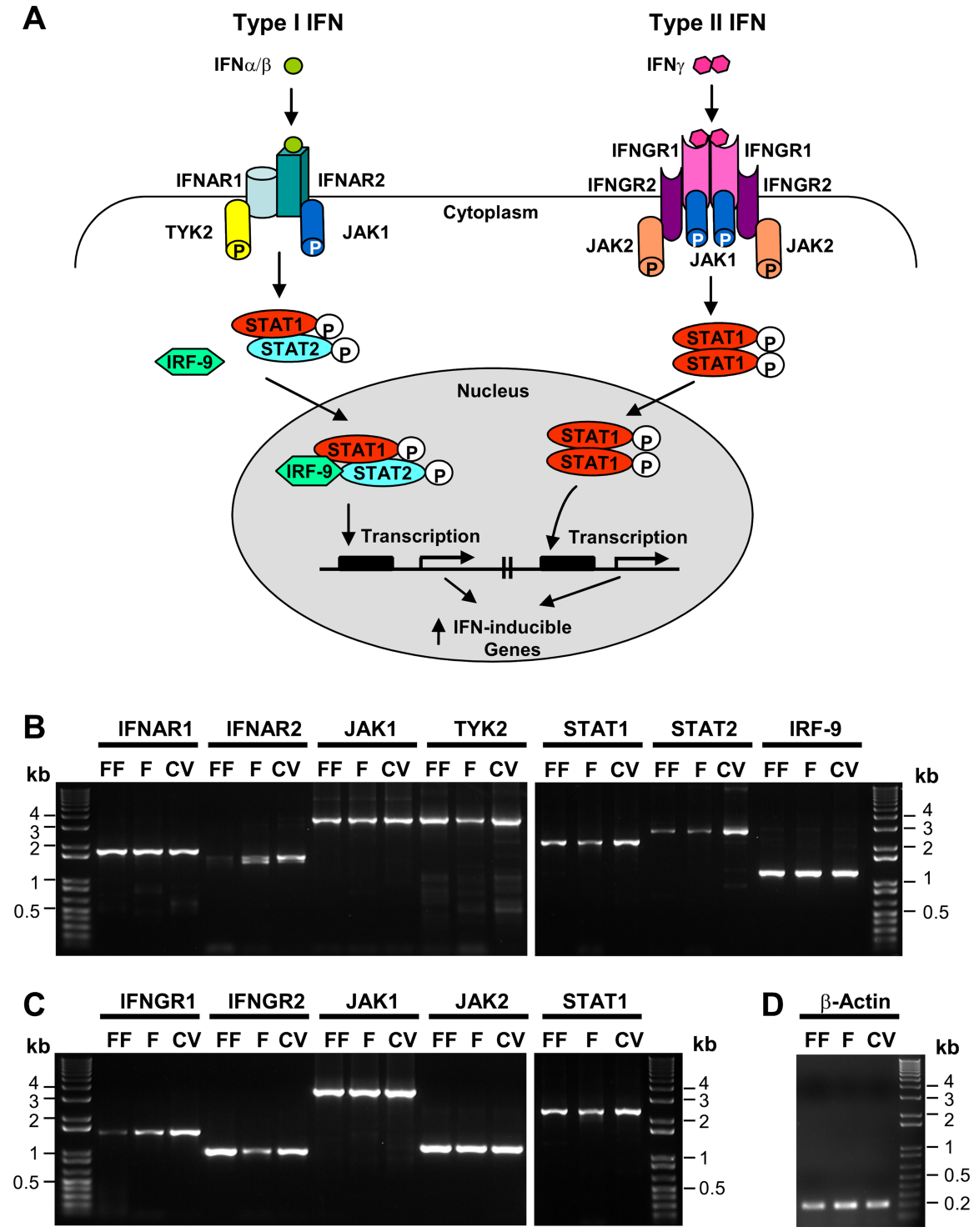

Figure 1. The major components of both type I and type II IFN signaling pathways found in taste epithelium. $\boldsymbol{A}$, Schematic drawing of IFN signaling pathways. On the left, the type I IFNs, such as IFN- $\alpha$ and IFN- $\beta$, bind to the IFNAR2 subunit of the heterodimeric receptor complex composed of IFNAR1 and IFNAR2. This binding triggers phosphorylation of JAK1 and TYK2 tyrosine kinases, which in turn phosphorylate STAT1 and STAT2 transcription factors. Phosphorylated STAT1 and STAT2 move into the nucleus and form a complex with IRF-9, which activates the transcription of many IFN-inducible genes. On the right, the type II IFN- $\gamma$ binds to the IFNGR1 subunit of the tetrameric receptor complex composed of two IFNGR1 and two IFNGR2 subunits. This engagement activates JAK1 and JAK2 kinases, which subsequently phosphorylate STAT1. The phosphorylated STAT1 forms a homodimer, translocates to the nucleus, and induces the expression of IFN- $\gamma$-inducible genes. $B, R T-P C R$ analyses of the expresson of genes in type I IFN signaling pathway in taste epithelium. RNA from lingual epithelium containing fungiform (FF), foliate pathway in taste epithelium. $\boldsymbol{D}, \mathrm{RT}-\mathrm{PCR}$ of $\beta$-actin was performed as a control. $0 \mathrm{n}$ the left and right in $\boldsymbol{B}-\boldsymbol{D}, 1 \mathrm{~Kb}$ Plus DNA Ladders (Invitrogen) serve as references for DNA band size. RT-PCR primers and the sizes of the predicted PCR products are listed in Table 1.

$1 B)$. Sequencing showed that these were two splice variants, the shorter one lacking exon 4 from the IFNAR2 gene. Although other splice isoforms have been reported previously (Lutfalla et al., 1995; Owczarek et al., 1997; Hardy et al., 2002), the splice out of exon 4 seems particularly interesting because exon 4 encodes part of the extracellular ligand-binding domain of the receptor (Hardy et al., 2002), and any deletions in this region may give this novel receptor variant a distinct binding specificity to the different type I IFNs (van Boxel-Dezaire et al., 2006).

Similarly, for the type II IFN signaling pathway, the genes 
A

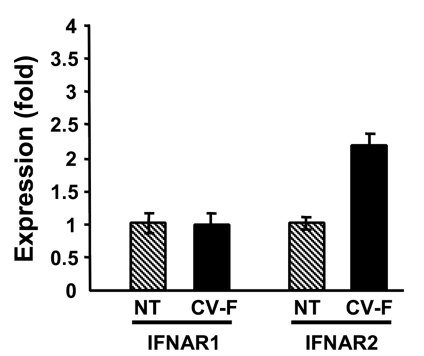

IFNGR1 Antisense

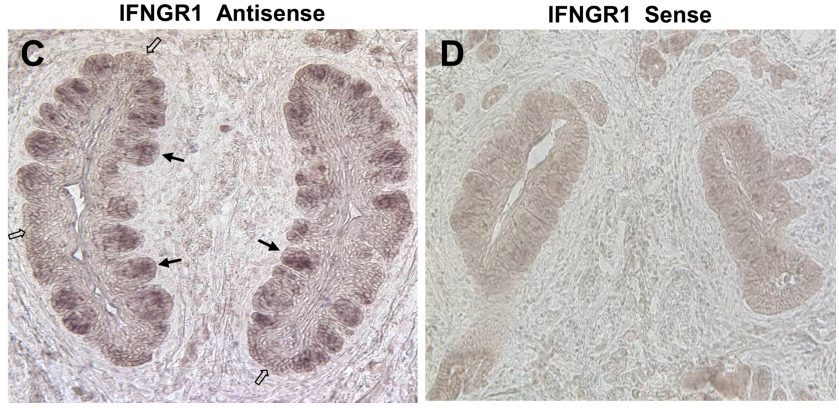

Figure 2. The ligand-binding subunit of the IFN- $\alpha$ receptor complex IFNAR2 and that of the IFN- $\gamma$ receptor complex IFNGR1 are expressed at higher levels in taste epithelium than in nontaste epithelium. $\boldsymbol{A}$, Real-time RT-PCR analyses of the IFN- $\alpha$ receptor subunits IFNAR1 and IFNAR2 in nontaste (NT) versus circumvallate and foliate-containing (CV-F) lingual epithelium. Relative quantification of expression level was determined using glyceraldehyde-3-phosphate dehydrogenase (Gapdh) as the endogenous control gene, and the expression level in nontaste samples was arbitrarily set to 1 . Error bars represent SEM. $\boldsymbol{B}$, Real-time RT-PCR analyses of the IFN- $\gamma$ receptor subunits IFNGR1 and IFNGR2 in nontaste (NT) verses circumvallate and foliatecontaining (CV-F) lingual epithelium. Data were analyzed as described in $\boldsymbol{A}$. Real-time PCR primers used in $\boldsymbol{A}$ and $\boldsymbol{B}$ are shown in Table 2. C, $\boldsymbol{D}$, Mouse circumvallate sections processed for in situ hybridization with antisense $(\boldsymbol{C})$ and sense $(\boldsymbol{D})$ probes to IFNGR1. Filled arrows, Representative taste buds; open arrows, intragemmal regions lacking taste buds.

encoding the two IFN- $\gamma$ receptor chains IFNGR1 and IFNGR2, the JAK kinases JAK1 and JAK2, and the transcription factor STAT1 are also expressed in these taste bud-containing epithelia (Fig. 1C).

To confirm the preferential expression of IFN receptors in taste bud cells compared with that in the surrounding nongustatory epithelial cells, we performed quantitative real-time PCR on several signaling genes. The results showed that IFNAR2, the ligand-binding subunit of the type I IFN receptor, was more abundantly expressed in taste epithelium compared with nontaste epithelium, whereas IFNAR1, the signaling subunit of the type I IFN receptor, was expressed at similar levels in taste and nontaste epithelia (Fig. 2A). Similarly, IFNGR1, the ligandbinding subunit of the type II IFN receptor, was preferentially expressed in taste epithelium but not the signaling subunit IFNGR2 (Fig. $2 B$ ). These expression patterns indicate that more IFN binding sites were present in taste epithelium than in nontaste lingual epithelium. In situ hybridization with antisense probes to IFNGR1 confirmed that the transcripts for IFNGR1 were expressed more abundantly in taste buds (indicated by filled arrows in Fig. 2C) than in nontaste epithelium (indicated by open arrows, Fig. $2 C$ ), whereas sense probes showed no nonspecific hybridization to lingual tissue (Fig. 2D). Together, these results demonstrate the presence of IFN signaling pathways in taste tissues, suggesting that both type I and type II IFNs can directly act on taste bud cells.
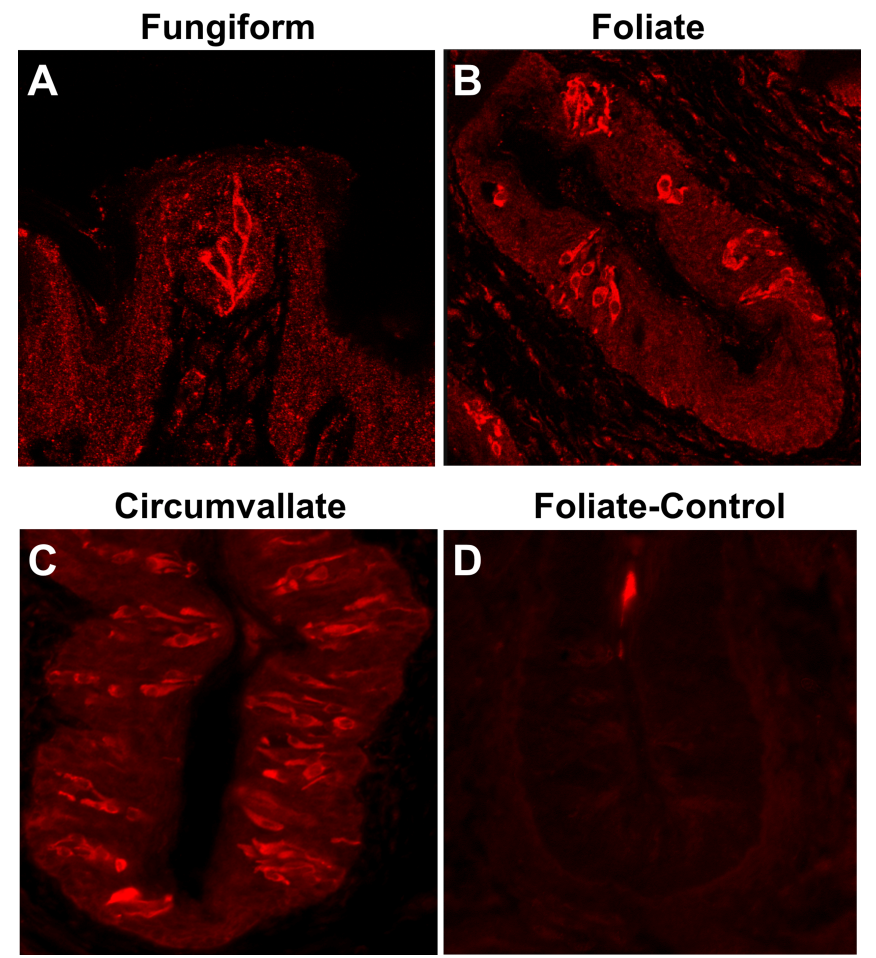

Foliate-Control

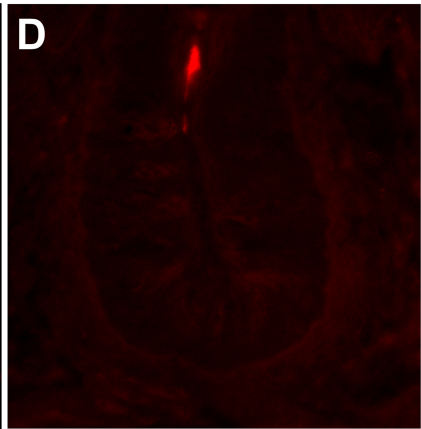

Figure 3. The IFN- $\gamma$ receptor subunit IFNGR1 is expressed in a subset of taste bud cells. $\boldsymbol{A}-\boldsymbol{C}$, Immunofluorescence images of rat fungiform, foliate, and circumvallate papillae stained with antibody against IFNGR1, showing that a subset of taste bud cells were immunoreactive to the antibody. D, Peptide competition. A foliate papilla section was stained with IFNGR1 antibody that had been preincubated with the antigenic peptide.

The IFN- $\gamma$ receptor subunit IFNGR1 proteins are localized to a subset of taste bud cells

Mammalian taste buds are composed of a heterogeneous population of 50-100 elongated cells and a small number of round basal cells (Stone et al., 2002; Finger, 2005). Based on their structure and morphology, these cells have been classified into types I, II, III, and IV (Murray, 1973; Kinnamon et al., 1985; Witt et al., 2003). Recent molecular studies have shown that different types of taste cells possess distinct molecular markers and play unique roles in taste transduction (Finger, 2005; Huang et al., 2007). To investigate what types of cells express the IFN signaling pathways, we performed immuno-colocalization studies with antibodies against the IFN- $\gamma$ receptor subunit IFNGR1 and one of the two known taste bud cell-type markers: (1) NCAM, present primarily in type III synaptic taste bud cells, and (2) the taste G-protein $\alpha$-gustducin that occurs in type II taste receptor cells. Consistent with the data from the aforementioned in situ hybridization experiments, IFNGR1 antibody strongly stained a subset of taste bud cells in rat fungiform, foliate, and circumvallate papillae (Fig. $3 A-C$, respectively), and preincubation of the antibody with its antigenic blocking peptide eliminated the immunoreactivity, confirming the specificity of this antibody (Fig. 3D).

In rat, double immunostaining with antibodies against IFNGR1 and NCAM showed that the majority of NCAMpositive type III cells also express IFNGR1 (Fig. 4A): 166 of 175 (95\%) NCAM-expressing cells also expressed IFNGR1, whereas 166 of $201(82.5 \%)$ IFNGR1-expressing cells also expressed NCAM. Conversely, 48 of 85 (56\%) of $\alpha$-gustducin-positive type II cells expressed IFNGR1 (Fig. 4B), whereas 48 of $116(41 \%)$ of IFNGR1-positive cells were immunoreactive to the gustducin antibody. This result suggests that both type II and type III taste receptor cells can be stimulated by IFN- $\gamma$. 
Recombinant IFNs activate cultured taste bud cells

Activation of the IFN signaling pathways often leads to phosphorylation of STAT1 transcription factor (Taniguchi and Takaoka, 2001; Kalvakolanu, 2003; van Boxel-Dezaire et al., 2006). To investigate whether the IFN signaling pathways present in taste buds can be functionally stimulated, we treated isolated taste and nontaste epithelia with the recombinant IFN $-\alpha$ and IFN- $\gamma$ and then determined the STAT1 phosphorylation levels using Western blot analyses with an antibody specifically against STAT1 phosphorylated at Tyr701.

As shown in Figure $5 A$ (top, p-STAT1), both IFN- $\alpha$ and IFN- $\gamma$ induced a marked increase in the phosphorylation of STAT1 in taste bud-containing samples (lane FF, fungiform epithelium; lane CV-F, circumvallate and foliate epithelium), whereas much less increase was detected in nongustatory lingual epithelia (NT) (Fig. $5 A, B)$. The noticeably low level of STAT1 phosphorylation in mock-treated control circumvallate and foliate samples may reflect basal IFN activity in these papillae or a minimal damageinduced inflammation brought about during the peeling of the epithelium. These results suggest that taste bud-containing epithelium is more sensitive to the action of IFNs than the nongustatory epithelium.

Systemic inflammation upregulates the expression of IFNinducible genes and downregulates the c-Fos expression in taste buds in vivo

The above-described studies using a primary culture of taste papillae-containing epithelium showed that IFN receptors likely located on the taste bud cells can be activated by exogenous IFNs. To further investigate whether the IFNs generated in vivo during infections are sufficient to trigger the IFN signaling pathways of the taste bud cells, we used two infection models: (1) the intraperitoneal injection of lipopolysaccharide, a major component of Gram-negative bacteria cell wall, which mimics bacterial infection by evoking systemic immune responses with the release of a spectrum of cytokines, including IFNs (Guha-Thakurta and Majde, 1997; Sakaguchi et al., 2003; Wang et al., 2003; Hodgson, 2006); (2) the intraperitoneal injection of the synthetic dsRNA poly(I:C), which can mimic an acute viral infection and release significant amounts of IFNs (Lengyel, 1987; Kimura-Takeuchi et al., 1992; Majde, 2000).

To verify the efficacy of these two compounds within the context of our conditions, we first tested the induction of IFNs in the spleen using real-time RT-PCR. Both agents could induce the expression of IFN- $\alpha$, IFN- $\beta$, and IFN- $\gamma$ in the spleen (data not shown).

To monitor the activation of IFN signaling pathways in taste tissue, we examined the change in expression levels of five well characterized IFN-inducible genes and the cellular activityrelated gene c-fos. Quantitative real-time RT-PCR revealed that both LPS and poly(I:C) significantly increased the mRNA levels of 2-5A synthetase, Irf1, Mx1, Pkr, and Stat1 genes in taste epithelium and, to a much lesser extent, in nongustatory lingual epithelium, as well (Fig. 6A).

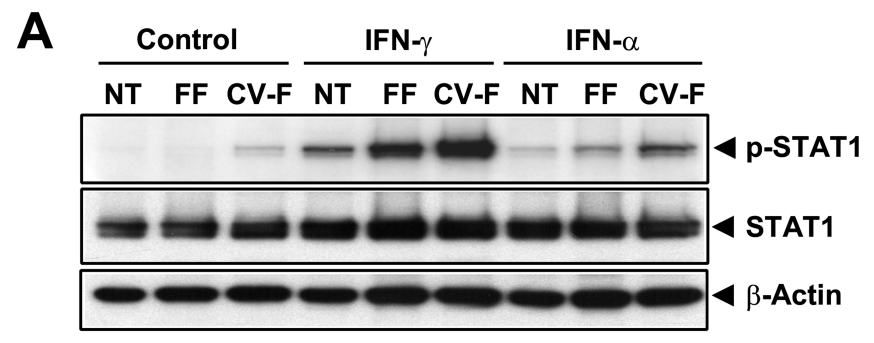

B

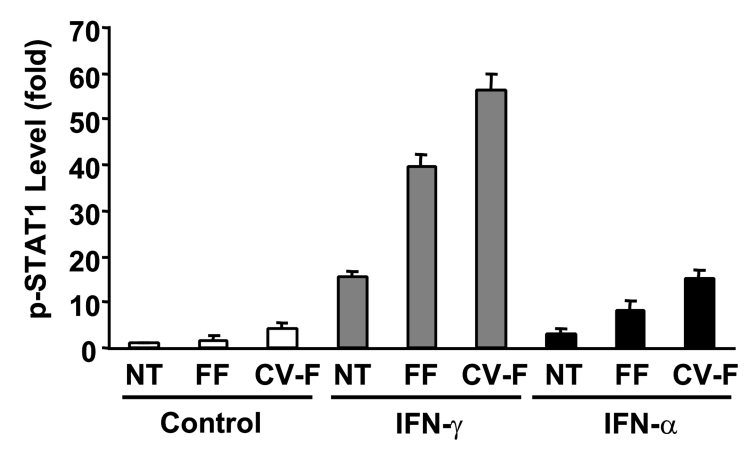

Figure 5. IFN- $\alpha$ and IFN- $\gamma$ induce phosphorylation of STAT1 at Tyr701 in taste epithelium. Lingual epithelial pieces were excised from regions that either were devoid of any taste buds (NT) or contained fungiform (FF) or circumvallate and foliate (CV-F) taste buds. Three parallel sets of samples were treated with recombinant murine IFN- $\alpha\left(5 \times 10^{3}\right.$ units $\left./ \mathrm{ml}\right)$, IFN- $\gamma(1 \times$ $10^{4}$ units $/ \mathrm{ml}$ ), or buffer only (control) for 1 h. $\boldsymbol{A}$, Top, Western blot using phospho-STAT1 (p-STAT1, Y701)-specific antibody. Middle and bottom, The membrane used in the top was stripped and reblotted with a polyclonal antibody against total STAT1 covering both STAT1 $\alpha$ and STAT $\beta$ (STAT1, middle) and a monoclonal antibody against $\beta$-actin (bottom). $\boldsymbol{B}$, Plot of signal intensities from Western blots in $\boldsymbol{A}$ analyzed using imaging software. The relative levels of p-STAT1 were normalized against the levels of $\beta$-actin in each sample. The level of p-STAT1 in the control nontaste sample was arbitrarily set to 1. Error bars represent SEM.

To confirm that it was the taste bud cells that were the principal sources for the marked elevation in the expression of these IFN-inducible genes, we performed in situ hybridization with probes to one of the five genes, Irf1, on circumvallate sections from LPS-treated mice. Figure $6 B$ shows that, after the treatment 
A
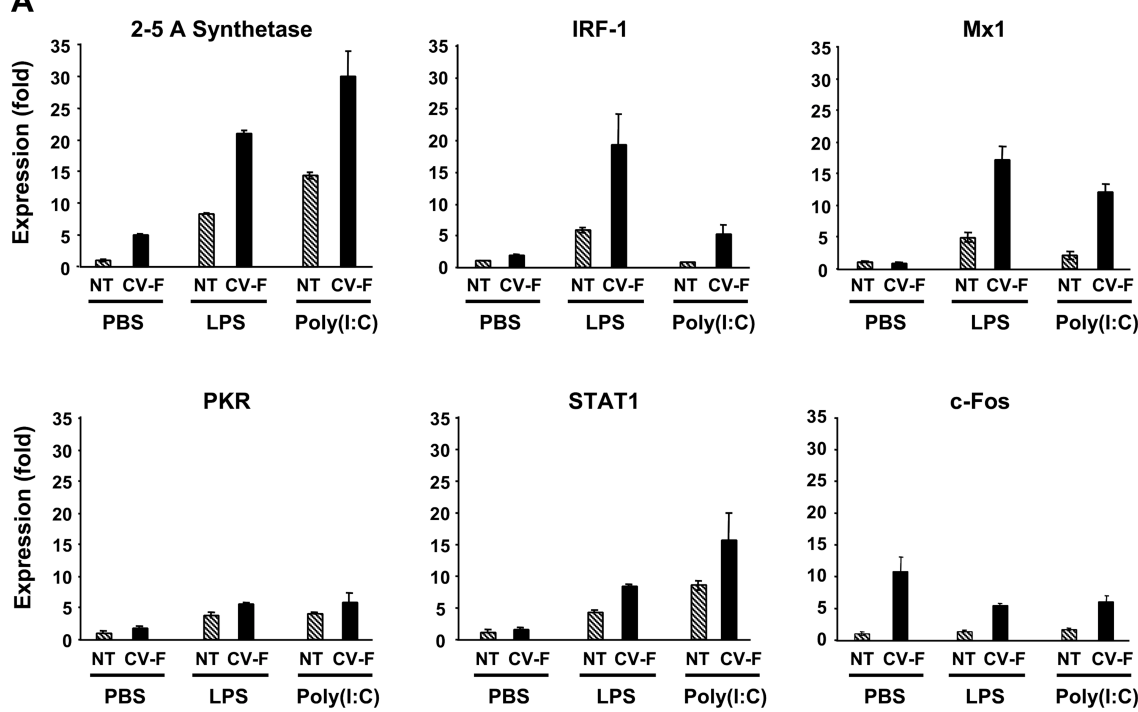

B

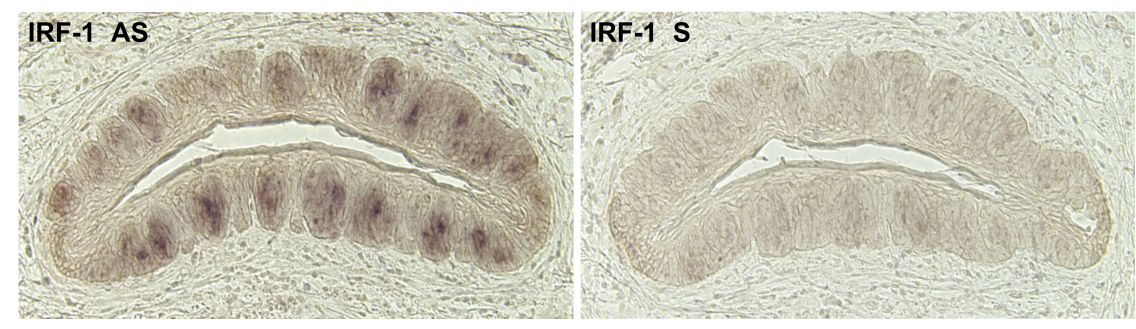

Figure 6. Inflammation induces the expression of IFN-inducible genes and decreases the level of c-fos mRNA in taste buds. $\boldsymbol{A}$ Mice were injected intraperitoneally with either placebo (PBS) or inflammatory stimuli [LPS, $5 \mathrm{mg} / \mathrm{kg}$ in PBS, or poly(l:C), 25 $\mathrm{mg} / \mathrm{kg}$ in PBS]. Six hours after injection, total RNA was isolated from nontaste (NT) and taste [circumvallate and foliate (CV-F)] lingual epithelium. Gene expression was analyzed by quantitative real-time RT-PCR. Data for five IFN-inducible genes (2-5A synthetase, Irf1, Mx1, Pkr, and Stat1) and the c-fos gene are shown. The relative expression levels of these genes were normalized using Gapdh as the endogenous control. The expression levels of these genes in PBS-treated nontaste samples were set to 1. Error bars represent SEM. The PCR primers used in this experiment are listed in Table 2. B, Expression of Irf1 in taste bud cells after LPS treatment. Mice were injected intraperitoneally with $5 \mathrm{mg} / \mathrm{kg}$ LPS. Six hours after injection, circumvallate tissues were processed for in situ hybridization with antisense (AS) or sense (S) probes to Irf1.

with LPS, Irf1 expression was predominantly in taste bud cells (left panel), whereas the negative control sense probe displayed little hybridization signal (right panel). Together, these two lines of evidence, one from real-time PCR and the other from in situ hybridization, suggest that both taste and nontaste lingual epithelia are sensitive to viral and bacterial infection-mediated inflammation but that IFNs can stimulate a more robust response in taste bud cells, including the modulation of genes such as Irf1 that play pivotal roles in initiating apoptosis (Tanaka et al., 1994; Novelli et al., 1996; Bernabei et al., 2001).

To investigate whether the inflammation-induced IFNs may also be able to alter the physiological function of the taste bud cells, we analyzed the level of c-fos mRNA in taste versus nontaste tissues in response to LPS and poly(I:C) treatment (Fig. 6A, bottom right). c-fos expression has been used extensively as a marker for cellular activity (Cao et al., 2002; Travers, 2002; Chan et al., 2004; Norlin et al., 2005). Our results show that c-fos expression is much higher in circumvallate and foliate papillae $(\mathrm{CV}-\mathrm{F})$ than in nontaste epithelium in control mice (PBS); however, the LPS and poly(I:C) treatments markedly reduced its expression in taste papillae but not in nontaste epithelium. This result indicates that inflammation may impair taste bud cell function and dampen taste signal transduction.
IFN treatments increase apoptotic cell death in taste buds

The increase in IRF-1 expression in taste bud cells during induction of systemic inflammation strongly suggests that, under these conditions, apoptosis of taste bud cells may be accelerated. Such acceleration can disrupt normal cell turnover of taste cells (Beidler and Smallman, 1965; Mistretta and Hill, 2003). To determine whether the elevated IRF-1 can initiate taste cell apoptosis, we examined the presence of two important indicators of cellular death: cleaved caspase-3 and cleaved PARP (Fig. 7). Intact caspase-3 has little proteolytic activity, yet when cleaved at a specific position, it is activated and able to degrade many other physiologically important proteins, including PARP (Nicholson et al., 1995). Functional PARP is known to be essential for the survival of cells, and fragmented PARP is used as a molecular marker of apoptosis (Garnier et al., 2003).

Our results showed that daily dosing of IFN- $\alpha$ and IFN- $\gamma$ for 2 or $5 \mathrm{~d}$ resulted in a significant increase in the number of taste buds that were immunoreactive to cleaved caspase-3 (Fig. $7 A, B$ ). Western blot analyses showed that incubation of cultured taste epithelium with either IFN- $\alpha$ or IFN- $\gamma$ elevated the amount of cleaved PARP preferentially in taste epithelium compared with nongustatory lingual epithelium (Fig. 7C), which is in agreement with the aforementioned results that the ligand-binding subunits of IFN receptors IFNAR2 and IFNGR1 are more abundantly present in taste papillae than in the nontaste lingual epithelium. These results suggest that IFN-triggered apoptosis in taste buds may be one of the mechanisms causing taste disorders.

\section{Discussion}

Recent studies suggest that inflammation contributes to the development of various chronic diseases, including neurodegenerative diseases, cancer, diabetes, and obesity (Coussens and Werb, 2002; Nathan, 2002; Shoelson et al., 2006; Zipp and Aktas, 2006). Its role in the pathogenesis of taste disorders has also been suggested because infections of various natures are often associated with chemosensory disorders, including those of taste (Henkin et al., 1975; Bartoshuk et al., 1987; Goodspeed et al., 1987; Cullen and Leopold, 1999; Bromley, 2000; Mann, 2002; Harris et al., 2006). More direct evidence that inflammation and taste are linked comes from the clinical observation that IFN therapy is very often accompanied by taste disorders (Jones and Itri, 1986; Kellokumpu-Lehtinen et al., 1989). To date, there has been a dearth of studies searching for inflammatory pathways that may contribute to gustatory disorders. To our knowledge, the present study is the first to demonstrate that taste buds express the IFN signaling pathways and that inflammation activates these pathways, resulting in upregulation of IFN-inducible genes and downregulation of c-fos mRNA in taste bud cells. Our study has 
also demonstrated that IFN treatment markedly increase apoptotic cell death in taste buds, which, we suggest, could be the cellular mechanism underlying taste dysfunctions associated with IFN therapy.

Results from the present study show that key components of both type I and type II IFN signaling pathways are expressed in taste epithelium (Fig. 1). Our quantitative real-time PCR and in situ hybridization experiments reveal that the ligand-binding subunits of the IFN- $\alpha$ and IFN- $\gamma$ receptor complexes, IFNAR2 and IFNGR1, respectively, are preferentially expressed in taste buds (Fig. 2). Furthermore, immunostaining using antibodies to IFNGR1 clearly labels subsets of taste bud cells in fungiform, foliate, and circumvallate papillae (Fig. 3). Immunocolocalization studies show that most of these cells are NCAM-positive type III taste cells, with a smaller proportion of $\alpha$-gustducin-positive type II cells (Fig. 4).

The coexpression of IFNGR1 with NCAM and, to a lesser extent, with $\alpha$-gustducin in taste bud cells suggests that these cells should be sensitive to IFN- $\gamma$. Indeed, in our in vitro IFN stimulation experiment, IFN- $\gamma$ induced a dramatic increase of STAT1 phosphorylation in the circumvallate and foliate samples compared with IFN induction of these proteins in nongustatory samples (Fig. 5). IFN- $\gamma$ has been shown to induce apoptosis in numerous cell types (Chin et al., 1997; Furuta et al., 2002; Chawla-Sarkar et al., 2003; Konur et al., 2005), and this IFN activity correlates with the amplitude and speed of STAT1 phosphorylation (Bernabei et al., 2001).

Consistent with these results, IFN- $\alpha$ and IFN- $\gamma$ significantly increased the number of apoptotic taste bud cells, most probably type II or type III cells (Fig. 7). Parallel observations have been made in another model of taste loss. In radiation-induced taste loss, degeneration of NCAM-positive (type III) taste cells was consistently observed (Nelson, 1998). In olfactory epithelium, increased apoptotic cell death caused by inflammation disturbs the balance of cell turnover and appears to be associated with olfactory dysfunction (Kern et al., 2004). Our study suggests that inflammation may contribute to taste disorders by similar mechanisms.

IFNs regulate the expression of many downstream genes (Sen and Lengyel, 1992; Der et al., 1998). The proteins encoded by these genes mediate the various functions of IFNs. Our results show that the expression of IFN-inducible genes in taste buds can be markedly elevated by inflammatory stimuli (Fig. 6). Among the five IFN-inducible genes investigated in our study, Stat1, Pkr, and Irf1 play important roles in IFN-induced apoptosis (Chin et al., 1997; Balachandran et al., 2000; Chawla-Sarkar et al., 2003). However, in normal cell turnover in taste buds, the p53- and Bax-dependent cell death pathway may be involved (Zeng and Oakley, 1999). Future experiments are needed to determine on the left.
PBS

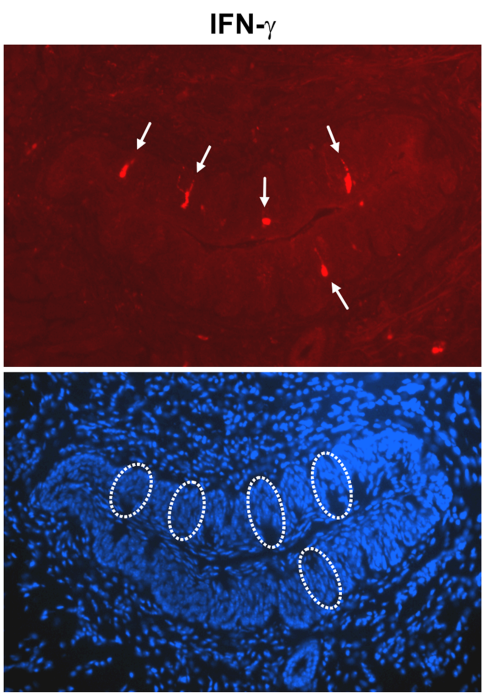

C

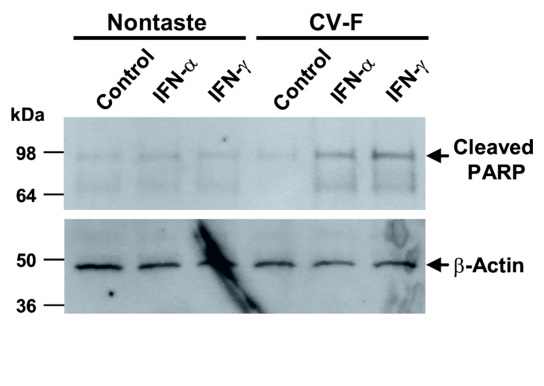

Figure 7. IFN treatments increase apoptotic cell death in taste buds. Mice were injected intraperitoneally with PBS, IFN- $\alpha$ $\left(5 \times 10^{3}\right.$ units in PBS per mouse), or IFN- $\gamma\left(2 \times 10^{4}\right.$ units in PBS per mouse) daily for 2 or $5 \mathrm{~d}$ as indicated. $A$, Representative munofluorescence images of circumvallate sections from PBS-treated or IFN- $\gamma$-treated mice (5 d) stained with cleaved pors mallate taste buds is represented as the percentage of cleaved caspase-3-positive taste buds. Error bars represent SEM ${ }^{*} p<0.05 ;{ }^{* *} p<0.001$. C, Peeled-off nontaste or taste [circumvallate and foliate (CV-F)] tongue epithelium was incubated for ysates were assayed by Western blot analysis for cleaved PARP and $\beta$-actin. The positions of molecular weight markers are shown

whether and how the IFN pathways crosstalk with the p53 or other cell death pathways in taste cells.

Interestingly, inflammation induced by LPS and poly(I:C) also altered the expression of c-fos mRNA in taste buds, but, in this case, the expression is suppressed. c-fos expression in taste buds has not been characterized before. Our results showed that the c-fos gene is preferentially expressed in taste buds and likely plays a role in gustatory signaling. The reduced expression of c-fos in taste buds implies that inflammation, in addition to its effect on taste cell turnover, may also obstruct taste signal transduction.

In addition to the end organs of taste, inflammation can also act on the nervous systems. Previous studies have documented activity of IFNs and other cytokines on both the CNS and peripheral nervous system (PNS) (Popko et al., 1997; Aubert and Dantzer, 2005; Dafny and Yang, 2005; Hagberg and Mallard, 2005). The blood-brain barrier of the CNS normally restricts access of components of the immune system to the brain. Nevertheless, repeated insults or a single high dose of an inflammationinducing agent often result in the transport of inflammatory signals across either the intact or the compromised CNS bloodbrain barrier. Immune attacks on the nervous systems affect food 


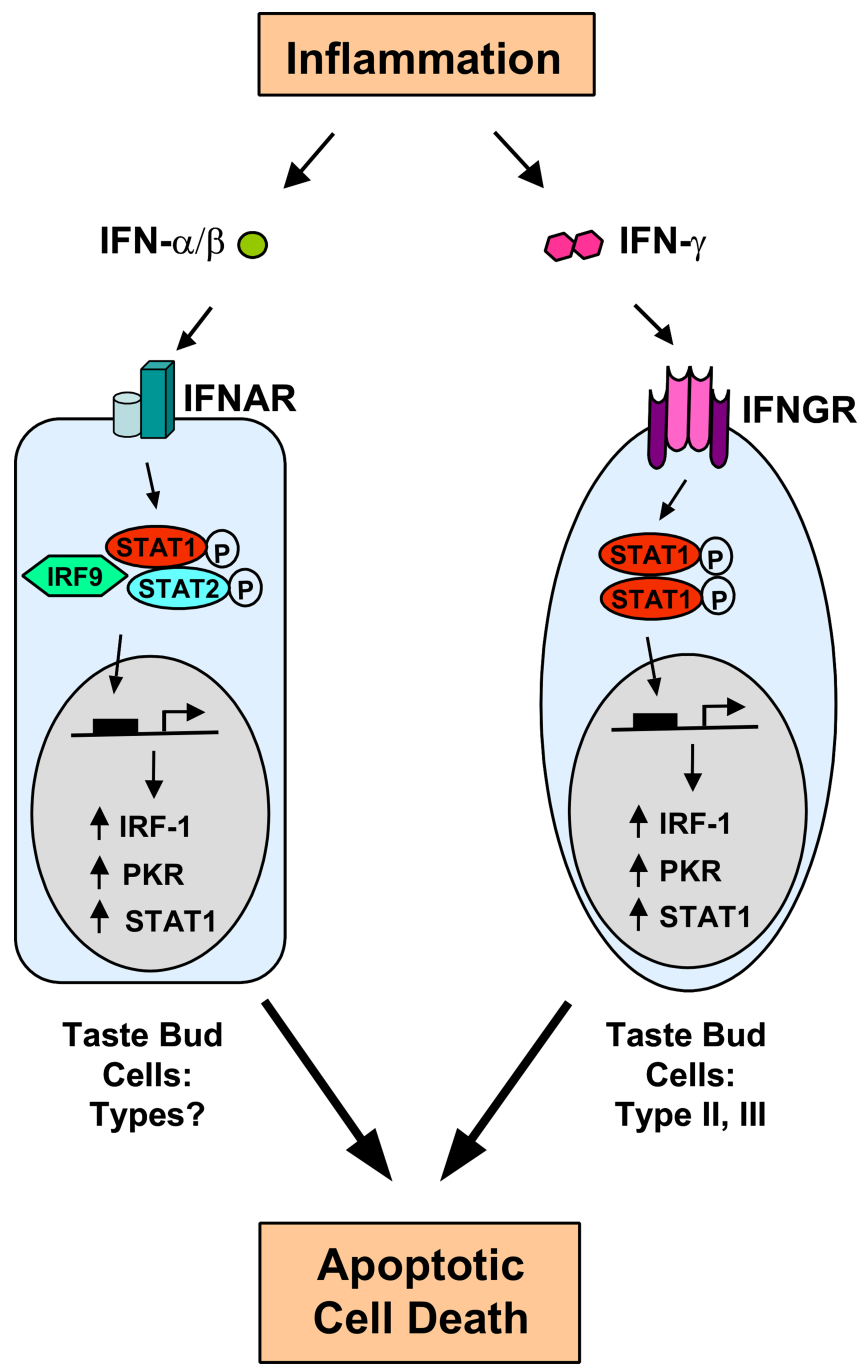

Figure 8. A model for inflammation-induced taste disorders. Inflammation caused by immune responses to infection, tissue damage, or autoimmunity releases type I (IFN- $\alpha / \beta$ ) and type II (IFN- $\gamma$ ) IFNs. IFNs bind to type I or II IFN receptors (IFNAR or IFNGR) on taste bud cells and trigger the phosphorylation of STAT proteins. Phosphorylated STAT proteins form active transcription complexes and stimulate the expression of IFN-inducible genes, including IrfI, Pkr, and Stat1. Highly induced expression of these genes increases apoptotic cell death in taste bud cells and results in a net loss of functional taste receptor cells.

and fluid intake and also taste sensation (Landis et al., 2005). Although of great value in understanding the impact of inflammation on the activity of gustatory neurons, such studies are beyond the scope of our current research. Rather, our data are consistent with the suggestion that IFN stimulation of taste bud cells is one mechanism by which inflammation leads to taste deficits. These may exacerbate any effects attributable to CNS compromise. More functional studies are needed to determine the impact of the immune system on taste buds, the peripheral nervous system, and the CNS.

Our model for inflammation-induced taste bud-mediated taste dysfunctions is described in Figure 8. Bacterial and viral infection, tissue damage, or autoimmune factors trigger inflammation and elevates the level of IFNs. IFNs activate their receptors (INFAR and INFGR) on taste bud cells, which in turn activate protein kinases that phosphorylate STAT1 and STAT2. Phosphorylated STAT proteins are transposed to the nucleus and there form active transcription complexes, inducing the expression of a number of genes. The expression of one of the inducible genes, IRF-1, promotes apoptosis of taste bud cells, eventually leading to the loss of taste sensation.

The concept emerging from our work suggests that IFN pathways play critical roles in the pathogenesis of taste disorders by robust induction of IFN-inducible genes and augmentation of apoptosis in taste receptor cells. However, because of the complexity of the cytokine network, it is possible that other inflammatory cytokines may also be involved. In this regard, our work suggests that, to prevent and mitigate taste disorders, nonsteroidal anti-inflammatory drugs or possible interferon antagonists could be administrated before and during inflammatory illnesses.

In summary, the results presented here show that taste bud cells, in particular, type III and some type II receptor cells, express IFN signaling pathways. These pathways can be activated by inflammation-induced factors and increase apoptotic cell death in taste buds. These results provide the first direct evidence that inflammation may affect taste tissue through cytokine signaling pathways and suggest a molecular basis for understanding the roles that IFNs may play in taste disorders.

\section{References}

Abdollahi M, Radfar M (2003) A review of drug-induced oral reactions. J Contemp Dent Pract 4:10-31.

Aubert A, Dantzer R (2005) The taste of sickness: lipopolysaccharideinduced finickiness in rats. Physiol Behav 84:437-444.

Balachandran S, Roberts PC, Brown LE, Truong H, Pattnaik AK, Archer DR, Barber GN (2000) Essential role for the dsRNA-dependent protein kinase PKR in innate immunity to viral infection. Immunity 13:129-141.

Banchereau J, Pascual V (2006) Type I interferon in systemic lupus erythematosus and other autoimmune diseases. Immunity 25:383-392.

Bartoshuk L, Desnoyers S, Hudson C, Marks L, O’Brien M (1987) Tasting on localized areas. Ann NY Acad Sci 510:166-168.

Begitt A, Meyer T, van Rossum M, Vinkemeier U (2000) Nucleocytoplasmic translocation of Stat 1 is regulated by a leucine-rich export signal in the coiled-coil domain. Proc Natl Acad Sci USA 97:10418-10423.

Beidler LM, Smallman RL (1965) Renewal of cells within taste buds. J Cell Biol 27:263-272.

Bernabei P, Coccia EM, Rigamonti L, Bosticardo M, Forni G, Pestka S, Krause CD, Battistini A, Novelli F (2001) Interferon- $\gamma$ receptor 2 expression as the deciding factor in human T, B, and myeloid cell proliferation or death. J Leukoc Biol 70:950-960.

Brämerson A, Johansson L, EK L, Nordin S, Benda M (2004) Prevalence of olfactory dysfunction: the skövde population-based study. Laryngoscope 114:733-737.

Bromley SM (2000) Smell and taste disorders: a primary care approach. Am Fam Physician 61:427-438.

Bromley SM, Doty RL (2003) Clinical disorders affecting taste: evaluation and management. In: Handbook of olfaction and gestation, Ed 2 (Doty RL, ed), pp 935-957. New York: Dekker.

Cao Y, Shreffler C, Herness S (2002) Localization and functional investigation of the transcription factor CREB in taste receptor cells. NeuroReport 13:1321-1325.

Caraglia M, Marra M, Pelaia G, Maselli R, Caputi M, Marsico SA, Abbruzzese A (2005) Alpha-interferon and its effects on signal transduction pathways. J Cell Physiol 202:323-335.

Chan CY, Yoo JE, Travers SP (2004) Diverse bitter stimuli elicit highly similar patterns of Fos-like immunoreactivity in the nucleus of the solitary tract. Chem Senses 29:573-581.

Chawla-Sarkar M, Lindner DJ, Liu YF, Williams BR, Sen GC, Silverman RH, Borden EC (2003) Apoptosis and interferons: role of interferonstimulated genes as mediators of apoptosis. Apoptosis 8:237-249.

Chin YE, Kitagawa M, Kuida K, Flavell RA, Fu XY (1997) Activation of the STAT signaling pathway can cause expression of caspase 1 and apoptosis. Mol Cell Biol 17:5328-5337.

Choubey D, Li SJ, Datta B, Gutterman JU, Lengyel P (1996) Inhibition of E2F-mediated transcription by p202. EMBO J 15:5668-5678.

Conger AD, Wells MA (1969) Radiation and aging effect on taste structure and function. Radiat Res 37:31-49.

Coussens LM, Werb Z (2002) Inflammation and cancer. Nature $420: 860-867$. 
Crow MK (2003) Type I interferon and autoimmune disease. Autoimmunity 36:445-446.

Cullen MM, Leopold DA (1999) Disorders of smell and taste. Med Clin North Am 83:57-74.

Dafny N, Yang PB (2005) Interferon and the central nervous system. Eur J Pharmacol 523:1-15.

Darnell JE (1997) STATs and gene regulation. Science 277:1630-1635.

Deems DA, Doty RL, Settle RG, Moore-Gillon V, Shaman P, Mester AF, Kimmelman CP, Brightman VJ, Snow JB (1991) Smell and taste disorders, a study of 750 patients from the University of Pennsylvania Smell and Taste Center. Arch Otolaryngol Head Neck Surg 117:519-528.

Der SD, Zhou A, Williams BRG, Silverman RH (1998) Identification of genes differentially regulated by interferon $\alpha, \beta$, or $\gamma$ using oligonucleotide arrays. Proc Natl Acad Sci USA 95:15623-15628.

Esses BA, Jafek BW, Hommel DJ, Eller PM (1988) Histological and ultrastructural changes of the murine taste bud following ionizing irradiation. Ear Nose Throat J 67:478-493.

Federici M, Giustizieri ML, Scarponi C, Girolomoni G, Albanesi C (2002) Impaired IFN-gamma-dependent inflammatory responses in human keratinocytes overexpressing the suppressor of cytokine signaling 1. J Immunol 169:434-442.

Finger TE (2005) Cell types and lineages in taste buds. Chem Senses 30:i54-i55.

Finger TE, Danilova V, Barrows J, Bartel DL, Vigers AJ, Stone L, Hellekant G, Kinnamon SC (2005) ATP signaling is crucial for communication from taste buds to gustatory nerves. Science 310:1495-1499.

Furuta S, Goto H, Niwa Y, Ohmiya N, Kamiya K, Oguri A, Hayakawa T, Mori $\mathrm{N}$ (2002) Interferon-gamma regulates apoptosis by releasing soluble tumor necrosis factor receptors in a gastric epithelial cell line. J Gastroenterol Hepatol 17:1283-1290.

Garnier P, Ying W, Swanson RA (2003) Ischemic preconditioning by caspase cleavage of poly(ADP-ribose) polymerase-1. J Neurosci 23:7967-7973.

Goodspeed RB, Gent JF, Catalanotto FA (1987) Chemosensory dysfunction. Clinical evaluation results from a taste and smell clinic. Postgrad Med 81:251-260.

Graham CS, Graham BG, Bartlett JA, Heald AE, Schiffman SS (1995) Taste and smell losses in HIV infected patients. Physiol Behav 58:287-293.

Gresser I (1990) Biologic effects of interferons. J Invest Dermatol 95:S66-S71.

Guha-Thakurta N, Majde JA (1997) Early induction of proinflammatory cytokine and type I interferon mRNAs following Newcastle disease virus, poly[rI:rC], or low-dose LPS challenge of the mouse. J Interferon Cytokine Res 17:197-204.

Hagberg H, Mallard C (2005) Effect of inflammation on central nervous system development and vulnerability. Curr Opin Neurol 18:117-123.

Hardy MP, Hertzog PJ, Owczarek CM (2002) Multiple regions within the promoter of the murine Ifnar-2 gene confer basal and inducible expression. Biochem J 365:355-367.

Harris R, Davidson TM, Murphy C, Gilbert PE, Chen M (2006) Clinical evaluation and symptoms of chemosensory impairment: one thousand consecutive cases form the dysfunction clinic in San Diego. Am J Rhinol 20:101-108.

Heald AE, Pieper CF, Schiffman SS (1998) Taste and smell complaints in HIV-infected patients. AIDS 12:1667-1674.

Henkin RI, Larson AL, Powell RD (1975) Hypogeusia, dysgeusia, hyposmia, and dysosmia following influenza-like infection. Ann Otol 84:672-682.

Hodgson JC (2006) Endotoxin and mammalian host responses during experimental disease. J Comp Pathol 135:157-175.

Hoffman HJ, Ishii EK, MacTurk RH (1998) Age-related changes in the prevalence of smell/taste problems among the United States adult population. Ann NY Acad Sci 855:716-722.

Huang L, Shanker YG, Dubauskaite J, Zheng JZ, Yan W, Rosenzweig S, Spielman AI, Max M, Margolskee RF (1999) Ggamma13 colocalizes with gustducin in taste receptor cells and mediates IP3 responses to bitter denatonium. Nat Neurosci 2:1055-1062.

Huang L, Cao J, Wang H, Vo LA, Brand JG (2005) Identification and functional characterization of a voltage-gated chloride channel and its novel splice variant in taste bud cells. J Biol Chem 280:36150-36157.

Huang YJ, Maruyama Y, Dvoryanchikov G, Pereira E, Chaudhari N, Roper SD (2007) The role of pannexin 1 hemichannels in ATP release and cell-cell communication in mouse taste buds. Proc Natl Acad Sci USA 104:6436-6441.

Jones GJ, Itri LM (1986) Safety and tolerance of recombinant interferon alfa-2a (Roferon-A) in cancer patients. Cancer 57:1709-1715.

Kalvakolanu DV (2000) Interferons and cell growth control. Histol Histopathol 15:523-537.

Kalvakolanu DV (2003) Alternate interferon signaling pathways. Pharmacol Ther 100:1-29.

Kellokumpu-Lehtinen P, Nordman E, Toivanen A (1989) Combined interferon and vinblastine treatment of advanced melanoma: evaluation of the treatment results and the effects of the treatment on immunological functions. Cancer Immunol Immunother 28:213-217.

Kern RC, Conley DB, Haines GK, Robinson AM (2004) Pathology of the olfactory mucosa: implications for the treatment of olfactory dysfunction. Laryngoscope 114:279-285.

Kimura-Takeuchi M, Majde JA, Toth LA, Krueger JM (1992) The role of double-stranded RNA in induction of the acute-phase response in an abortive influenza virus infection model. J Infect Dis 166:1266-1275.

Kinnamon JC, Taylor BJ, Delay RJ, Roper SD (1985) Ultrastructure of mouse vallate taste buds. I. Taste cells and their associated synapses. J Comp Neurol 235:48-60.

Konur A, Schulz U, Eissner G, Andreesen R, Holler E (2005) Interferon (IFN)-gamma is a main mediator of keratinocyte (HaCaT) apoptosis and contributes to autocrine IFN-gamma and tumour necrosis factor-alpha production. Br J Dermatol 152:1134-1142.

Kraus I, Vitezic D (2000) Anosmia induced with alpha interferon in a patient with chronic hepatitis C. Int J Clin Pharmacol Ther 38:360-361.

Landis BN, Konnerth CG, Hummel T (2004) A study on the frequency of olfactory dysfunction. Laryngoscope 114:1764-1769.

Landis BN, Beutner D, Frasnelli J, Huttenbrink KB, Hummel T (2005) Gustatory function in chronic inflammatory middle ear diseases. Laryngoscope 115:1124-1127.

Lee SB, Rodriguez D, Rodriguez JR, Esteban M (1997) The apoptosis pathway triggered by the interferon-induced protein kinase PKR requires the third basic domain, initiates upstream of Bcl-2, and involves ICE-like proteases. Virology 231:81-88.

Lengyel P (1987) Double-stranded RNA and interferon action. J Interferon Res 7:511-519.

Livak KJ, Schmittgen TD (2001) Analysis of relative gene expression data using real-time quantitative PCR and the $2^{-\Delta \Delta C t}$ method. Methods 25:402-408.

Lutfalla G, Holland SJ, Cinato E, Monneron D, Reboul J, Rogers NC, Smith JM, Stark GR, Gardiner K, Mogensen KE, Kerr IM, Uze G (1995) Mutant U5A cells are complemented by an interferon- $\alpha \beta$ receptor subunit generated by alternative processing of a new member of a cytokine receptor gene cluster. EMBO J 14:5100-5108.

Majde JA (2000) Viral double-stranded RNA, cytokines, and the flu. J Interferon Cytokine Res 20:250-272.

Mann NM (2002) Management of smell and taste problems. Cleveland Clin J Med 69:329-336.

Mistretta CM (1984) Aging effects on anatomy and neurophysiology of taste and smell. Gerontology 3:131-136.

Mistretta CM, Hill DL (2003) Development of the taste system: basic neurobiology. In: Handbook of olfaction and gustation. Ed 2 (Doty RL, ed), pp 759-782. New York: Dekker.

Murphy C, Schubert CR, Cruickshanks KJ, Klein BE, Klein R, Nondahl DM (2002) Prevalence of olfactory impairment in older adults. JAMA 288:2307-2312.

Murray RG (1973) The ultrastructure of taste buds. In: The ultrastructure of sensory organs (Friedmann I, ed), pp 1-81. Amsterdam: North Holland Publishing.

Nathan C (2002) Points of control in inflammation. Nature 420:846-852.

Nelson GM (1998) Biology of taste buds and the clinical problem of taste loss. Anat Rec 253:70-78.

Nicholson DW, Ali A, Thornberry NA, Vaillancourt JP, Ding CK, Gallant M, Gareau Y, Griffin PR, Labelle M, Lazebnik YA, Munday NA, Raju SM, Smulson ME, Yamin T, Yu VL, Miller DK (1995) Identification and inhibition of the ICE/CED-3 protease necessary for mammalian apoptosis. Nature 376:37-43.

Norlin EM, Vedin V, Bohm S, Berghard A (2005) Odorant-dependent, spatially restricted induction of $c$-fos in the olfactory epithelium of the mouse. J Neurochem 93:1594-1602. 
Novelli F, Bernabei P, Ozmen L, Rigamonti L, Allione A, Pestka S, Garotta G, Forni G (1996) Switching on of the proliferation or apoptosis of activated human T lymphocytes by IFN-gamma is correlated with the differential expression of the alpha- and beta-chains of its receptor. J Immunol 157:1935-1943.

Owczarek CM, Hwang SY, Holland KA, Gulluyan LM, Tavaria M, Weaver B, Reich NC, Kola I, Hertzog PJ (1997) Cloning and characterization of soluble and transmembrane isoforms of a novel component of the murine type I interferon receptor, IFNAR 2. J Biol Chem 272:23865-23870.

Perez CA, Huang L, Rong M, Kozak JA, Preuss AK, Zhang H, Max M, Margolskee RF (2002) A transient receptor potential channel expressed in taste receptor cells. Nat Neurosci 5:1169-1176.

Pestka S (1997) The interferon receptors. Semin Oncol 24:S9-S40.

Popko B, Corbin JG, Baerwald KD, Dupree J, Garcia AM (1997) The effects of interferon-gamma on the central nervous system. Mol Neurobiol 14:19-35.

Pribitkin E, Rosenthal MD, Cowart BJ (2003) Prevalence and causes of severe taste loss in a chemosensory clinic population. Ann Otol Rhinol Laryngol 112:971-978.

Pumplin DW, Getschman E (2000) Synaptic proteins in rat taste bud cells: appearance in the Golgi apparatus and relationship to alpha-gustducin and the Lewis. (b) and A antigens. J Comp Neurol 427:171-184.

Royuela M, de Miguel MP, Ruiz A, Fraile B, Arenas MI, Romo E, Paniagua R (2000) Interferon-gamma and its functional receptors overexpression in benign prostatic hyperplasia and prostatic carcinoma: parallelism with c-myc and p53 expression. Eur Cytokine Netw 11:119-127.

Saito A, Narasimhan P, Hayashi T, Okuno S, Ferrand-Drake M, Chan PH (2004) Neuroprotective role of a proline-rich Akt substrate in apoptotic neuronal cell death after stroke: relationships with nerve growth factor. J Neurosci 24:1584-1593.

Sakaguchi S, Negishi H, Asagiri M, Nakajima C, Mizutani T, Takaoka A, Honda K, Taniguchi $\mathrm{T}$ (2003) Essential role of IRF-3 in lipopolysaccharide-induced interferon-beta gene expression and endotoxin shock. Biochem Biophys Res Commun 306:860-866.

Sánchez-Gómez MV, Alberdi E, Ibarretxe G, Torre I, Matute C (2003) Caspase-dependent and caspase-independent oligodendrocyte death mediated by AMPA and kainate receptors. J Neurosci 23:9519-9528.

Schaeren-Wiemers N, Gerfin-Moser A (1993) A single protocol to detect transcripts of various types and expression levels in neural tissue and cultured cells: in situ hybridization using digoxigenin- labelled cRNA probes. Histochemistry 100:431-440.

Schiffman SS, Graham BG (2000) Taste and smell perception affect appetite and immunity in the elderly. Eur J Clin Nutr 54:S54-S63.

Sen GC, Lengyel P (1992) The interferon system. A bird's eye view of its biochemistry. J Biol Chem 267:5017-5020.

Shoelson SE, Lee J, Goldfine AB (2006) Inflammation and insulin resistance. J Clin Invest 116:1793-1801.

Spagnoli A, Torello M, Nagalla SR, Horton WA, Pattee P, Hwa V, Chiarelli F, Roberts CT, Rosenfeld RG (2002) Identification of STAT-1 as a molecular target of IGFBP-3 in the process of chondrogenesis. J Biol Chem 277:18860-18867.
Stetson DB, Medzhitov R (2006) Type I interferons in host defense. Immunity 25:373-381.

Stone LM, Tan SS, Tam PPL, Finger TE (2002) Analysis of cell lineage relationships in taste buds. J Neurosci 22:4522-4529.

Tanaka N, Ishihara M, Kitagawa M, Harada H, Kimura T, Matsuyama T, Lamphier MS, Aizawa S, Mak TW, Taniguchi T (1994) Cellular commitment to oncogene-induced transformation or apoptosis is dependent on the transcription factor IRF-1. Cell 77:829-839.

Taniguchi T, Takaoka A (2001) A weak signal for strong responses: interferon-alpha/beta revisited. Nat Rev Mol Cell Biol 2:378-386.

Theofilopoulos AN, Baccala R, Beutler B, Kono DH (2005) Type I Interferons $(\alpha / \beta)$ in Immunity and Autoimmunity. Annu Rev Immunol 23:307-335.

Travers SP (2002) Quinine and citric acid elicit distinctive Fos-like immunoreactivity in the rat nucleus of the solitary tract. Am J Physiol Regul Integr Comp Physiol 282:R1798-R1810.

van Boxel-Dezaire AHH, Rani MRS, Stark GR (2006) Complex modulation of cell type-specific signaling in response to type I interferons. Immunity 25:361-372.

Wang H, Liu C, Lu Y, Chatterjee G, Ma XY, Eisenman RN, Lengyel P (2000) The interferon- and differentiation-inducible $\mathrm{p} 202 \mathrm{a}$ protein inhibits the transcriptional activity of c-Myc by blocking its association with Max. J Biol Chem 275:27377-27385.

Wang H, Ding B, Liu CJ, Ma XY, Deschamps S, Roe BA, Lengyel P (2002) The increase in levels of interferon-inducible proteins p202a and p202b and RNA-dependent protein kinase (PKR) during myoblast differentiation is due to transactivation by MyoD: their tissue distribution in uninfected mice does not depend on interferons. J Interferon Cytokine Res 22:729-737.

Wang H, Yu M, Ochani M, Amella CA, Tanovic M, Susarla S, Li JH, Wang H, Yang H, Ulloa L, Al-Abed Y, Czura CJ, Tracey KJ (2003) Nicotinic acetylcholine receptor alpha7 subunit is an essential regulator of inflammation. Nature 421:384-488.

Witt M, Reutter K, Miller IJ (2003) Morphology of the peripheral taste system. In: Handbook of olfaction and gestation, Ed 2 (Doty RL, ed), pp 651-677. New York: Dekker.

Yamashita H, Nakagawa K, Tago M, Nakamura N, Shiraishi K, Eda M, Nakata H, Nagamatsu N, Yokoyama R, Onimura M, Ohtomo K (2006) Taste dysfunction in patients receiving radiotherapy. Head Neck 28:508-516.

Yee CL, Yang R, Böttger B, Finger TE, Kinnamon JC (2001) “Type III” cells of rat taste buds: immunohistochemical and ultrastructural studies of neuron-specific enolase, protein gene product 9.5, and serotonin. J Comp Neurol 440:97-108.

Yeh SS, Schuster MW (1999) Geriatric cachexia: the role of cytokines. Am J Clin Nutr 70:183-197.

Zeng Q, Oakley B (1999) p53 and Bax: putative death factors in taste cell turnover. J Comp Neurol 413:168-180.

Zipp F, Aktas O (2006) The brain as a target of inflammation: common pathways link inflammatory and neurodegenerative diseases. Trends Neurosci 29:518-527. 